\title{
The Impact of Risk Committee on Financial Performance of UK Financial Institutions
}

\author{
Ahmed A. Elamer* \\ Institute for Accounting and Financial Markets \\ School of Business and Enterprise \\ University of the West of Scotland \\ Paisley, PA1 2BE, UK \\ Email: ahmed.a.elamer@gmail.com \\ Department of Accounting \\ Faculty of Commerce \\ Mansoura University \\ Mansoura, Egypt \\ *Corresponding author \\ Ismail Benyazid \\ Accounting Department \\ Faculty of Economics and Trade \\ Asmarya University \\ Zliten, Libya \\ Email: ismailr218@gmail.com
}

\section{Biographical notes:}

Ahmed A. Elamer ( $\mathrm{PhD}$, University of Huddersfield, UK) is a Lecturer in Accounting, Accounting, Finance and Law Cluster, School of Business and Enterprise, University of the West of Scotland, UK. His research interests focus on narrative disclosures, social and environmental accounting, and corporate governance. He has published in the Journal of Applied Accounting Research and Business \& Society.

Ismail Benyazid (MSc, University of Huddersfield, UK) is a lecturer in accounting at The Asmarya University. He graduated from Asmarya University, with a BSc degree in Accounting. He holds an MSc in Accounting from the University of Huddersfield. His research interests focus on corporate governance, risk-taking and corporate performance in financial institutions.

${ }^{*}$ Corresponding author; Address for correspondence: Institute for Accounting and Financial Markets, Gardner Building, UWS School of Business and Enterprise, University of the West of Scotland, Paisley Campus, High Street, Paisley, PA1 2BE, UK. Tel: +44 (0) 141849 4390; E-mail: ahmed.elamer@uws.ac.uk and/or ahmed.a.elamer@gmail.com. 


\title{
The Impact of Risk Committee on Financial Performance of UK Financial Institutions
}

\begin{abstract}
Following the recent financial crisis, Walker (2009) recommended that financial institutions should form a separate board level risk committee (RC) to manage various risks and prevent excessive risk taking. This research focuses on investigating how firms with separate risk committees differ from those that do not have one. The main research question we address is whether RCs have a fundamental influence on financial performance. We measure financial performance by ROA and ROE and we control for firm size, liquidity and gearing. Our sample consists of all listed financial institutions in FTSE-100 index from 2010 through 2014. Results indicate a negative relationship between risk committee characteristics (i.e., existence, size, independence, and meeting frequency) and financial performance. The results also indicate that firms without risk committee (RC) performed considerably well than firms with RC. The results are contradictory to Walker's (2009) where RCs are recommended for their ability to mitigate and manage risks more expertly. However, we argue that establish strong RC constrain management ability to make excessive risk taking behaviour which may affect financial performance negatively. We contribute to the current research on the impact of risk committee governance attributes on financial performance after banking and governance reforms.
\end{abstract}

Keywords: Corporate Governance; Risk Management; Risk Committee; Financial Institutions; UK. 


\section{Introduction}

This research seeks to explore the relationship between risk committees (RC) as a key corporate governance mechanism in UK financial institutions (FIs) on financial performance. The failure of many FIs to fully integrate risk management practices into the corporate governance (CG) led to massive failures at a global level (BCBS, 2015; Berger et al., 2016; Core et al., 2006; Dermine, 2013, Elamer, 2017). The FIs performance and accountability and their behaviour regarding risk-taking have come under increased scrutiny (Aebi et al., 2012; Berger et al., 2016; BCBS, 2015; Hines \& Peters, 2015). Moreover, poor governance systems were determined as main causes of financial crisis. BCBS (2015), Berger et al. (2016), Elamer et al. (2016), Erkens et al. (2012) and Gupta et al. (2013) pointed out that poor governance systems including poor board control over management as well as poor risk management practices in FIs due to complex and opaque structures of FIs. Conventionally, risk management practices were part of audit committee responsibilities. However, it was recommended to split risk management responsibilities and establish independent committee due to major regulatory reforms, complex risk environment, claimed multiple roles and major scandals (BCBS, 2015; Ng et al., 2012; Walker, 2009). Research suggests that establishment of separate $\mathrm{RC}$ enable the firms to perform better and reduce agency problems as compared to the entire board (Moore \& Brauneis, 2008). This is why separate RCs are helpful for organizations that have complex structures, high agency costs, high leverage, size, or risk structure (Deloitte, 2011).

Thus, many FIs establish independent risk committees to cover responsibilities such as, suggest risk appetite and risk limits, limit breaks and mitigation procedures, review risk profile and risk monitoring, receive and review risk issues reports, stress test scenarios, and review, update and accept risk policies change (Battaglia et al., 2014; BCBS, 2015; Elamer et al., 2017; Ng et al., 2012). Therefore, RC as internal corporate governance structure can 
improve and assist the board of directors in managing risks in FIs. Thus, RC can contribute to FIs in many ways. RC with independent member and sufficient knowledge can maintain FIs at reasonable risk level effectively. RC contributes to FIs corporate governance generally via review and gives the board of directors' recommendation about risk management policies, plans and risk reasonable levels. RC also analyses and appraises how the risk management strategies and policies framework are effective in recognizing, quantifying, monitoring, and directing risks. More specific duties of an RC, as defined by Choi (2013) include: determining various risk management objectives to develop an enterprise wide strategy of risk management; making sure that a comprehensive risk management system is put into place by the management; communicating with executive members of the organization including CEO and CRO to report directly; reviewing the policies, procedures and techniques needed to implement risk management practices at every level of the organization; overseeing and monitoring risk transfer strategies and insurance policies. It should be noted that the role of the committee is to oversee and recommended, rather than make decisions. The authority to make decisions lies with the board itself, while the execution and implementation lie with the management. However, RCs strengthen the quality of risk management procedures and policies as well as improving communication regarding risk management among the different stakeholders including management and the board. Thus, the lessons learned from the performance of financial firms before and during the crisis have heightened the criticality of risk management and the formation of RCs within FIs (Al-Hadi et al., 2015; Hines \& Peters, 2015).

Walker (2009) and Basel Committee (2010) both emphasize the establishment of a separate RC within financial FIs, however, empirical evidence in the support of a relationship between RCs and firm performance is rare. Nestor (2009) reports that by the end of 2008, more than half $(52 \%)$ of Europe's largest 25 FI banks had a stand-alone RC, although no 
evidence was found between the existence of the committee and crisis avoidance. Mongiardino and Plath (2010) show that, regardless of heightened regulatory pressures, improvements in the risk management practices amongst banks have a long way to go. Another solution given by researchers is the appointment of a Chief Risk Officer (CRO) for overseeing the risk management activities of banks. According to findings by Nestor (2009), only one of the 25 largest European Banks had a CRO on the board in 2007. According to Zemzem \& Kacem (2014), who examined the influence of RC and financial performance (CFP) of the 17 lending company on Tunisia, during 2007-11 as well compare between FIs have RC and do not have. The findings show a negative association between RC and CFP. However, Minton et al. (2011) examined the impact of having RCs on CFP on 252 US bank institutions from 2003-08. The result shows a positive association between the existence of RC on the board of a bank and CFP.

Therefore, the research problem is that many reports (BCBS, 2015; Walker, 2009) claim that independent RCs can improve risk management and hence avoid financial crisis, but empirical evidence is limited. Thus, this research aims to gauge how RCs can impact the CFP of the FIs, with a focus on the UK financial sector. To do so, this study aims to develop the link between the existence of RCs and different characteristics of the committee and CFP, and show how there is a different impact on CFP between FIs that have RC, and those that do not. Using data from UK FIs. The fact that similar FIs weathered the market collapse differently indicates that internal governance and risk management mechanisms play an important role in organizational performance, more so during the crisis (Alnabsha et al., 2018; Essen et al., 2013; Kirkpatrick, 2009; Mongiardino \& Plath, 2010). The rationale, given by Choi (2013) is that, since audit committees (AC) are already overwhelmed with responsibilities relating to internal control and financial reporting, they are unable to handle risk management in an efficient manner (Clark et al., 2007). Moreover, the complex nature of 
risk management, and the skills required to manage risks, does not necessarily match with the skills of AC members. Battaglia et al. (2014) and Zaman (2001) assert that because of their lack of expertise and time, ACs do not offer a solution to risk management that is robust enough, considering the fact that ACs are already over-burdened because of additional responsibilities of abiding by the code of CG and regulatory reforms. Based on these lessons, recommendations put forward by Walker (2009), at the request of the Prime Minister of the UK, emphasize the establishment of a board level separate risk committee (RC) in banks and other financial institutions with the responsibility to oversee current and future risks.

The UK CG Code of 2014 does not necessitate the establishment of a separate RC, but recommends that companies should have a separate RC and also emphasizes that the board should monitor and control risks at a strategic as well as operational level and report the risks at least annually. Mongiardino and Plath (2010) showed in their research on 20 large banks (with assets of more than US\$300 billion at the end of 2008) from Europe and North America that, despite the increase in the trend towards the formation of a separate $\mathrm{RC}$ following the crisis, the trend has not become common. Empirical evidence by Yatim (2010) reveals a positive influence of $\mathrm{RC}$ on firm performance, while Aebi et al. (2012) suggest that a RC is not necessarily a viable solution as it adds to the expenses while not eradicating all types of risks. The number of these articles, nevertheless, is scant, because of the relative newness of $\mathrm{RC}$ in the financial sector in general, and in the context of the UK financial sector in particular. Therefore, this research explores how effective RCs are for FIs by establishing the association between RCs and CFP.

This study offers many contributions. First, it provides important insights into FIs that have already established separate RCs, so that they can measure whether their committees are actually fulfilling their functions, or adding costs. Second, the regulators and policy makers should work together to standardize risk management procedures as well as disclosing risk 
management practices in the annual report to help the shareholders in better understanding of the risk management practices. The disclosure will also encourage organizations to make sure their RCs are fulfilling their responsibilities and are not being marred by bureaucratic policies.

The remains of the paper is organised as follows. Section 2 reviews the literature on RC and CFP. Section 3 outlines the research design and variables measurement. Section 4 reports and discusses the empirical results. Section 5 concludes.

\section{Empirical literature and hypotheses development}

\subsection{Risk Committee Existence and CFP}

Agency theory predicts that formation of RCs might monitor managers' behaviour towards risk management and ensure that investment is in line with strategic goals to avoid financial crisis via decrease adverse selection and moral hazard which can impact performance (Aebi et al., 2012; Bhagat \& Bolton, 2008, Jensen \& Meckling, 1976; Minton et al., 2014; Peni \& Vähämaa, 2012; Yatim, 2010; Weir \& Laing, 2001). Aebi et al. (2012) argue that FIs continued to look to risk management as a support function or committee and consider growth in assets and reduction in costs as the main drivers of profitability, however, the recent financial crisis made it clear that the main business of FIs is to manage risks (Aebi et al., 2012). This notion is also enforced by Oluwafemi et al. (2013) by saying that banks and other FIs are exposed to a higher degree of risks compared to non-FIs because of the fact that the proportion of borrowed funds is much larger than the equity in the balance sheet.

Aebi et al. (2012), using a sample size of 54-85 banks available in the US during the period 2006 to 2008, investigated how risk governance related activities influence the performance of banks during the financial crisis. The performance was measured through ROE and buy-and-hold returns. The results revealed that banks with a CRO on the board had 
negative performance during the crisis. Another study by Minton et al. (2011) investigated the impact of establishing RCs on CFP on 252 large US banking institutions from 2003 to 2008. The findings show there is a positive association between the existence of RC and CFP. Hines and Peters (2015) examined the determinants and outcomes of voluntary formation of risk committees in US FIs from 1994 to 2008. The researchers collected data from the FIs who voluntarily formed RCs any time between 1994 and 2008. The findings revealed that formation of a RC did not have an association with performance. Yatim (2010) examined the relationship between RC and board structure in FIs based on data collected from 690 Malaysian firms listed on Bursa, Malaysia, at the end 2003. The results showed that there is poor performance by those firms with the existence of a RC during this period. In a research on Tunisian lending institutions by Zemzem and Kacem (2014) over the period of 2002 and 2011 using OLS regression, the researchers explored the relationship between RC and firm performance and made a comparison between companies that have a $\mathrm{RC}$ and those that do not. The study revealed a negative relationship between the existence of a separate RC and CFP. Based on the empirical evidence from similar studies, following hypothesis is developed to establish the relationship between risk management committee and firm's financial performance:

Hypothesis 1: There is a negative impact of the RC existence on CFP.

Hypothesis 2: There is a significant difference in CFP between firms with RC and those without $R C$.

\subsection{Risk Committee Size and CFP}

The size of the committee has important consequences on its performance and capabilities. According to Erkens et al. (2012) and Smith Report (2003) RC must have at least three members to ensure proper functioning. DeFond and Francis (2006) assert that the committee should be supported with sufficient authority and resources in order to operate fully. Agency theory predicts that increase size of RCs with varied knowledge might increase 
monitor managers' behaviour towards risk management and ensure that investment in line with strategic goals to avoid financial crisis via decrease adverse selection and moral hazard which can impact performance (Aebi et al., 2012; Jensen \& Meckling, 1976; Yatim, 2010).

Empirical findings reveal that the size of the committee can have a positive or a negative effect. For instance, Bedard et al. (2004) argue that the larger the size of the committee, the more diversity and expertise it can have to make more efficient recommendations to the board. This argument is supported by the resource dependency theory as well, which asserts that the larger committee can mean greater resources for addressing problems and issues. Research by Adams (2010) on board size and performance found negative association with performance, and an ambiguous relationship with risk. According to the findings, the larger boards increase complexity. On the other hand, Singh and Davidson (2003) and Wu et al. (2006) identified that the larger boards in general, the more challenging it becomes to communicate and coordinate, which translates into poor CFP. However, both these studies focused on the overall board of directors, rather than RCs size. According to the Smith Report (2003), the number of directors on audit and/or RC should be at least three. Vafeas (2005) and Dalton et al. (1999) raise concerns regarding free riding and lost focus in case of large size of committee. Zemzem and Kacem (2014) investigated the impact of a separate RC on CFP of the lending companies of Tunisia. They found that larger board size leads to poor CFP; which means a negative association between the board size of the RC and CFP. Furthermore, Battaglia and Gallo (2015) used data from the Asian financial sector focusing on Indian and Chinese banks to establish the relationship between boards of directors with risk management related mechanisms with CFP during the financial collapse of 2007-08. The results revealed no significant relationship between performance and $\mathrm{RC}$ size. $\mathrm{Ng}$ et al. (2012) investigated the relationship between RCs characteristics and risk taken by insurance firms in Malaysia during the period from 2003 to 2011. They also examined and identified 
three characteristics such as size, percentage of independent directors, and number of meetings by gathering data from 329 insurance firms. Their results have shown that there is significant negative association between size of RC and CFP. Moreover, another study, by Ellul and Yerramilli (2011), also found a negative relationship between the size of RC and CFP by examining 75 bank holding companies during the period 2002 to 2007 . On the other hand, a study done by Hines and Peters (2015), who examined the voluntary formations of RC by using data collected from 47 financial institutions in the USA during the period 1994 to 2008, using ROA and ROE as measurement for CFP, found a positive association. Whereas, Aebi et al. (2012) used sample sizes of 54-85 banks in to investigate how the existence of CRO or RC on the Executive Board impacted the CFP during the financial crisis. The study found a negative association between the size of the RC and CFP.

However, the research by Kallamu and Saat (2013), who investigated the impact of the structure of corporate governance on financial performance by collecting data from 37 FIs listed in the financial sector in Malaysia, using ROA and Tobin's Q as measurement for performance during the period 2007 to 2011, indicates that there is a positive relationship between the RC size and CFP. Another study in this regard was conducted by Hoque et al. (2013) and found a significant negative association between RC size and CFP. Therefore, based on these contradicting empirical evidence, the following hypothesis is generated:

\section{Hypothesis 3: The RC size a negative impact on CFP}

\subsection{Risk Committee Independence and CFP}

From a theoretical point of view, agency theory suggests that when directors from outside the company or independent directors are appointed on the board, the corporate governance mechanism improves generally (Dionne \& Triki, 2005). This implies that an outside director has an incentive to build the reputation as "expert monitors" which is why they are more likely to take proper control of the firm. Yet another argument in favour of independent 
directors is that since outside directors do not have their careers tied to the company, they can make decisions in a more efficient way without the fear of having their careers jeopardized (Dionne \& Triki, 2005). A large body of research has focused on effectiveness of independent directors. According to Hudson et al. (2001) and Wu et al. (2006), a larger number of independent directors on the board means that directors are more objective in making decisions. These empirical findings suggest the theoretical claim that independent directors are less capable of controlling governance mechanisms of organization as compared to internal directors. Similarly, agency theory asserts that the composition of the board plays a significant role in corporate governance.

Bhagat and Black (2002) negate the monitoring effect theory by finding no significant link between directors' independence and firm performance. With respect to the impact of outside directors on risk management function activities of firms, Borokovich et al. (2004) reveal that the usage of interest rate derivatives increased with the inclusion of outside directors on the board, leading to high riskiness of the business. Similarly, Marsden and Prevost (2005) and Dionne and Triki (2005) find no significant association between risk management, and the independent of director. $\mathrm{Ng}$ et al. (2012) examined the association between board characteristics and risk taken by insurance institutions listed on the Malaysia stock exchange during the period from 2003 to 2011. The study finds that there is a significance negative relationship between size of RC and CFP.

Zemzem and Kacem (2014) investigated the relationship between RC and CFP in Tunisian lending firm during the period 2002 to 2011 . The study finds a positive association between the percentages of independent RC members and CFP. Kallamu and Saat (2013) also find a positive association between percentages of independence directors on RC and CFP, and also found a positive association with market valuation of the firms. On the other hand, Yeh et al. (2011) investigated the voluntary formation of RC and CFP on FIs, by collecting 
data from 20 of the largest FIs from a group of industrial nations during the period from 1994 to 2008 and the Credit Crunch. The study finds a strong negative relationship between the percentage of independent directors and CFP. Therefore, it can be hypothesized that:

Hypothesis 4: Independent RC's directors have negative impact on CFP.

\subsection{Risk Committee Meetings and CFP}

According to the Smith Report (2003), the RC should meet at least three times per year. The primary motive of establishing $\mathrm{RC}$ is to ensure that risk is assessed, evaluated, managed and communicated on a regular basis so that there is no delay in risk management actions. Agency theory predicts that regular meetings of committees are important because infrequency can cause ineffectiveness (Abbott \& Parker., 2000; Menon \& Williams., 1994). The frequency of meetings also indicates the amount of effort being put in to accomplish the tasks and responsibilities (Sori et al., 2009). Jackling and Johl (2009) argue that the frequency of meetings of the board can play an active role in linking the external environment to the governance of the company, and can have a positive influence on the performance of the company. Abbott and Parker (2000) report that the greater the number of meetings, the less the chance there is for fraudulent reporting and activities. However, a research by Ferrero et al. (2012) reveal that higher frequency of board meetings is only effective in times of crisis and negatively impacts the performance of the firm during expansionary times. Based on this empirical evidence, it can be fairly assumed that the frequency of committee meetings has a profound effect on the performance of the committee itself, as well as on the tasks it aims to accomplish. According to the UK's Corporate Governance Code (2014), all board committee members of listed UK companies are required to attend the annual general meeting. This is made compulsory so that all committee members can share their insights with the board. Similarly, FRC (2014) requires all committees to meet every quarter and more frequently if required by specific circumstances. 
There are a limited number of studies conducted to investigate the relationship between the number of RC meetings and CFP. Hoque et al. (2013) examine how the number of AC and RC meetings influences CFP. Hoque et al. (2013) found no association between number of RC meetings and CFP. On the other hand, Ellul and Yerramilli (2011) examined the relationship between a separate $\mathrm{RC}$ and risk. The study shows that those companies that were less involved in mortgage backed securities and risky assets fared well during the crisis because they were less exposed to downside risk. Ellul and Yerramilli (2011) argued that strong and independent directors on the board of the RC are helpful in preventing losses and mitigating various kinds of risks in today's FIs. However, the study found there is a positive association between number of RC meetings and CFP. Aebi et al. (2012) and Ng et al. (2012) found that there is a negative association between the number of RC meetings and CFP. However, Battaglia and Gallo (2015) found a positive association between the RC size and CFP. Therefore, on the premise that higher frequency of meetings can render more effective risk management activities, the following hypothesis is generated:

\section{Hypothesis 5: The frequency of meetings of the RC has a negative impact on CFP}

\section{Research Design}

\subsection{Describing the characteristics of the sample and data considerations}

This study aims to investigate the relationship between RCs and CFP of listed FIs in the UK. The study period ranges from 2010 to 2014, which represents the aftermath the global financial crisis and subsequent strategies of FIs to mitigate risks and also after Walker report 2009. At the same time, using 2010 as a starting point for the research provides a good insight into the effects of the Walker's Report (2009), which suggests that all listed FIs should have a separate RC at board level. This research uses all companies listed in the financial sector in the 100 FTSE on 31/12/2014 to address the research problem and to 
answer the research questions. Thus, our sample consists of 23 companies, whether FIs have RCs or/and FIs without RCs as shown in Table 1.

Table 1: sample selection procedure

\begin{tabular}{|l|l|l|}
\hline sample attributes & No of companies & No of observations \\
\hline Total firms in 100 FTSE on 31/12/2014 & 100 & 500 \\
\hline - non financial firms in 100 FTSE on 31/12/2014 & 77 & 385 \\
\hline $\begin{array}{l}\text { = financial firms in 100 FTSE on 31/12/2014 } \\
\text { (final sample) }\end{array}$ & 23 & 115 \\
\hline
\end{tabular}

\subsection{Definition of variables and model specification}

We use a number of variables that are utilised as independent variables and used as indicators of effectiveness of RC, such as the size of RC, percentage of independent directors, and frequency of meetings of RC. The dependent variable in this study is CFP. In the analysis, we carry out three main test which are; descriptive statistics to present the nature and distribution of data, correlation to present initial evidence about the relation between variables, OLS regression to show the impact of risk committee characteristics on performance. The OLS regression models are as follow:

$$
C F P_{i t}=\alpha_{0}+\beta_{i} R C D_{i t}+\beta_{i} \sum_{i=1}^{4} \operatorname{CONTROLS_{it}}+\varepsilon_{i t}
$$

Where CFP represent corporate financial performance of company $i$ at time $t$ measured by Return on Assets (ROA), and Return on Equity (ROE). RCD refer to risk committee which measured by (i) RCEX represent existence of risk committee, (ii) RCNE represent percentage of non-executive directors to total number of directors in RC, (iii) RCSZ represent number of directors in RC, (iv) RCME represent frequency of risk committee meetings. CONTROLS refers to BASI represent firm size, LIQR represents liquidity ratio, GER represents gearing ratio, B4 refers to audit quality and YEARS are dummy variables for each year from 2009 to 2014. $\varepsilon$ is the error. Table 2 represent the variables definition which used in the study. To perform additional test, this study measure corporate financial performance by the most two common measure in prior studies which are: ROA and ROE. The data was collected from 
two sources. First, corporate financial performance data collected from FAME database. Second, the four RC characteristics variables were collected from annual reports. This study used data from the annual report for each company for each year from the financial statement during the period from 2010 to 2014. 
Table 2 variables definition

\begin{tabular}{|l|l|l|}
\hline Variables & Abbreviation & Description \\
\hline Dependent variable: corporate financial performance (CFP) \\
\hline Return on assets & ROA & Net income to total assets. \\
\hline Return on equity & ROE & Net income to total equity. \\
\hline Independent variables & \multicolumn{2}{|l|}{} \\
\hline existence of risk committee & RCEX & $\begin{array}{l}1 \text { if there is risk committee in the company, } \\
0 \text { otherwise. }\end{array}$ \\
\hline $\begin{array}{l}\text { percentage of non-executive } \\
\text { directors }\end{array}$ & RCNE & $\begin{array}{l}\text { Non-executive directors to total number of } \\
\text { directors in RC. }\end{array}$ \\
\hline RC size & & Total number of directors in RC. \\
\hline frequency of risk committee \\
meetings & RCME & Total number of RC meetings held in this \\
& & year. \\
\hline firm size & BASI & Firm total assets. \\
\hline Liquidity & LIQR & $\begin{array}{l}\text { Current assets to current liabilities of a } \\
\text { bank. }\end{array}$ \\
\hline Gearing & YEAR & $\begin{array}{l}\text { A percentage of debt scaled by equity. } \\
1 \text { if the FI audited by Big 4, 0 otherwise. }\end{array}$ \\
\hline Audit quality & GER & B4 fiscal year, 0 otherwise. \\
\hline Year dummies &
\end{tabular}

\section{Findings and Discussion}

\subsection{Descriptive, univariate and bivariate analyses}

Table 3 shows the descriptive statistics for the sample. It shows that the average financial performance of FIs under consideration, as measured through ROA is $4.75 \%$, which is significantly higher than the ROA reported as $1.2 \%$ and $1.06 \%$ by Hines and Peters (2015) and Aebi et al. (2012) which has done in USA, respectively. The difference might be attributed to the fact that the data for this study were collected for the period after the crisis, rather than during the crisis and the data collected from UK. Although the median of $0.94 \%$ is compare to these cited studies, the mean is higher because of a very high standard deviation of $9.37 \%$. Table 3 also reveals that only $74 \%$ of the 23 firms had separate RCs, with a 
standard deviation of 44. Ellull and Yerrailli (2010) report $33 \%$, whereas a study by Deloitte (2013) reports that $68 \%$ of the FIs in 2011 had separate board level RCs.

Table 3: Descriptive Statistics

\begin{tabular}{lrrrrr}
\hline Variables & Mean & Median & Std. Deviation & Minimum & Maximum \\
\hline ROA & 4.75 & 0.94 & 9.37 & -16.89 & 48.86 \\
ROE & 20.49 & 15.69 & 25.67 & -29.58 & 130.52 \\
RCEX & 0.74 & 1.00 & 0.44 & 0.00 & 1.00 \\
RCNE & 53.87 & 75.00 & 43.16 & 0.00 & 100.00 \\
RCME & 3.98 & 4.00 & 3.11 & 0.00 & 13.00 \\
RCSZ & 3.87 & 4.00 & 3.18 & 0.00 & 14.00 \\
BASI & 291862.19 & 24954.00 & 480441.98 & 189.00 & 1689308.00 \\
LIQR & 1.52 & 1.00 & 3.74 & 0.06 & 39.71 \\
GER & 162.39 & 59.00 & 554.35 & 0.10 & 637.00 \\
B4 & .96 & 1.00 & 0.20 & 0.00 & 1.00 \\
\hline
\end{tabular}

Notes: This table represents the descriptive statistics. This table show the following variables: Return on Assets (ROA), Return on Equity (ROE), RC existence (RCEX), RC independence (RCNE), RC size (RCSZ), RC meetings (RCME), firm size (BASI), liquidity (LIQR), gearing (GER), and audit quality (B4). See Table 2 for the definitions of each variable.

*** Denotes significant at the $1 \%$ level.

** Denotes significant at the $5 \%$ level.

* Denotes significant at the $10 \%$ level

With respect to the size of committee, the average size of RC in Table 3 is 3.87 with a standard deviation of $3.18 \%$. The result is higher than the recommended committee size of at least three members by the CG Code (2012) and Smith (2003). Nevertheless, these numbers are comparable to the findings of Aebi et al. (2012) who reported average number of directors to be $2.82 \%$. However, the results are slightly lower than reported by Battaglia and Gallo (2015), i.e. 3.96 per cent; Deloitte (2013) also reports the average number of members in the risk committee as found in 2011 to be 5. The results also show that the average percentage of non-executive directors in the RCs is 53.87 per cent with a standard deviation of $43.16 \%$. This result is also considerably lower than that reported by Aebi et al. (2012) at $56.44 \%$. Lastly, the frequency of meetings average is 3.98 times a year in Table 3, which is higher 
than that reported by Battaglia and Gallo (2015) of 1.85 meetings per year. However, the result is much lower than that reported by Aebi et al. (2012) with an average of 4.14 times per year. Some researcher argue that increase meeting frequency and independent board might increase effectiveness of risk committee which might affect performance (Aebi et al., 2012; Ng et al., 2012).

The correlation findings are shown in Table 4. There is a negative relationship between the ROA and existence of risk committee (corr $=-.177$, $\mathrm{p}$-value $=.058)$. Also, the ROA was negatively correlated with percentage of non-executive directors (corr $=-.389$, p-value $<$ $0.001)$, directors in risk committee $($ corr $=-.383$, $\mathrm{p}$-value $<.0001)$ and frequency of meeting (corr $=-.382, \mathrm{p}$-value $<.0001)$. 
Table 4: Correlation results

\begin{tabular}{|c|c|c|c|c|c|c|c|c|c|c|}
\hline Variables & ROA & ROE & RCEX & RCSZ & RCNE & RCME & BASI & LIQ & GEAR & B4 \\
\hline ROA & 1 & & & & & & & & & \\
\hline ROE & $0.747 * *$ & 1 & & & & & & & & \\
\hline RCEX & -0.140 & -0.031 & 1 & & & & & & & \\
\hline RCSZ & $-0.368 * *$ & $-0.262 * *$ & $0.767 * *$ & 1 & & & & & & \\
\hline RCNE & $-0.417 * *$ & -0.166 & $0.738 * *$ & $0.616 * *$ & 1 & & & & & \\
\hline BASI & $-0.307^{* *}$ & $-0.307^{* *}$ & $0.327^{* *}$ & $0.378^{* *}$ & $0.440^{* *}$ & $0.576^{* *}$ & 1 & & & \\
\hline LIQ & 0.130 & -0.003 & 0.066 & 0.006 & 0.045 & -0.159 & -0.079 & 1 & & \\
\hline GEAR & -0.069 & -0.090 & 0.052 & 0.010 & -0.110 & 0.006 & -0.019 & 0.035 & 1 & \\
\hline B4 & -0.079 & -0.093 & $0.367^{* *}$ & $0.282^{* *}$ & $0.271^{* *}$ & $0.268^{* *}$ & 0.120 & 0.024 & 0.023 & 1 \\
\hline
\end{tabular}

Notes: This table represents the correlation results. This table show the following variables: Return on Assets (ROA), Return on Equity (ROE), RC existence (RCEX), RC independence (RCNE), RC size (RCSZ), RC meetings (RCME), firm size (BASI), liquidity (LIQR), gearing (GER), and audit quality (B4). See Table 2 for the definitions of each variable.

** Denotes significant at the $1 \%$ level.

* Denotes significant at the 5\% level. 


\subsection{Regression analyses}

The result of the OLS regression models of the ROA was given in Table 5, while the result of the OLS regression models of the ROE was given in Table 6. Due to high correlation between RC characteristics, we made separate model for every RC aspect. Firstly, this study finds that the presence of separate RCs has a significant negative impact on CFP by $-4.893 \%$ and significant by $(\mathrm{p}$-value $=0.001)$. See Tables 5 and 6 , since the firms with no RCs performed better than firms with RCs. These results are deduced from the correlation analysis. This finding is similar to the result found by a research on Tunisian lending institutions by Zemzem and Kacem (2014) and Mubwandarika (2013). However, this finding is different from the findings of Yeh et al. (2011) who found a positive relationship between the presence of the RC and ROA. This negative relationship can be explained by agency theory as well as information asymmetry theory which assert that the information asymmetry or gap that can result because of the creation of a separate $\mathrm{RC}$ can result in problems relating to communication and thus lead to conflicts. Therefore, the results of this study can be justified in the light of the argument presented by Hines and Peters (2015) that the formation of a RC serves a symbolic role by signalling to the shareholders that responsible risk management actions are being taken. This is the reason that accounting based performance measures, such as ROA, do not support the positive influence of RCs on firm's profitability, at least in this particular research. Hence, Hypothesis 1 is accepted, that there is a negative influence of the existence of a separate RC on the firm's CFP. This implies that formation of separate RCs is one of the prominent initiatives taken by the CG regime in the banking and financial sector. This implies that firms constrained by excessive risk are less profitable and are also more likely to have a separate risk committee. While Walker (2009) increasingly encouraged banks and other FIs to form separate RCs to manage risks, researchers such as Aebi et al. (2012) have empirically proved the significant negative impact of separate RCs on 
overall firm performance. The rationale for forming separate RCs is that by forming a standalone $\mathrm{RC}$ with dedicated objectives, risk management practices can be improved.

Table 5: The Impact of RC on Financial Performance (ROA)

\begin{tabular}{|c|c|c|c|c|c|c|c|c|c|c|c|c|}
\hline & \multirow{2}{*}{\multicolumn{3}{|c|}{$\begin{array}{c}\text { Model } 1 \\
\text { Dependent variable: } \\
\text { ROA }\end{array}$}} & \multirow{2}{*}{\multicolumn{3}{|c|}{$\begin{array}{l}\text { Model } 2 \\
\text { endent variable: } \\
\text { ROA }\end{array}$}} & \multirow{2}{*}{\multicolumn{3}{|c|}{$\begin{array}{l}\text { Model } \mathbf{3} \\
\text { ROA }\end{array}$}} & \multirow{2}{*}{\multicolumn{3}{|c|}{$\begin{array}{c}\text { Model } 4 \\
\text { Pependent variable: } \\
\text { ROA }\end{array}$}} \\
\hline & & & & & & & & & & & & \\
\hline & $\mathbf{t}$ & Sig. & VIF & $\mathbf{t}$ & Sig. & VIF & $\mathbf{t}$ & Sig. & VIF & $\mathbf{t}$ & Sig. & VIF \\
\hline Constant & $4.859^{* * * *}$ & .000 & & $4.851^{* * *}$ & .000 & & $5.566^{* * *}$ & .000 & & $5.253^{* * *}$ & .000 & \\
\hline RCEx & $-4.893^{* * *}$ & .000 & 1.019 & - & - & - & - & - & - & - & - & - \\
\hline RCNE & - & - & - & $-5.676^{* * *}$ & .000 & 1.009 & - & - & - & - & - & - \\
\hline RCME & - & - & - & - & - & - & $-5.791^{* * *}$ & .000 & 1.030 & - & - & - \\
\hline RCSZ & - & - & - & - & - & - & - & - & - & $-5.727^{\text {**** }}$ & .000 & 1.019 \\
\hline BASI & $-2.915^{* * * *}$ & .004 & 1.140 & $-3.390^{* * *}$ & .001 & 1.262 & $-2.924^{* * *}$ & .003 & 1.530 & $-3.942^{* * * *}$ & .000 & 1.188 \\
\hline LIQ & 1.202 & .232 & 1.059 & 1.599 & .113 & 1.058 & 0.768 & .444 & 1.073 & 1.391 & .167 & 1.052 \\
\hline GEAR & -0.824 & .412 & 1.043 & -1.384 & .169 & 1.055 & -0.787 & .433 & 1.041 & -0.780 & .437 & 1.041 \\
\hline B4 & -0.172 & .864 & 1.282 & 0.595 & .553 & 1.213 & 0.270 & .787 & 1.194 & 0.417 & .677 & 1.212 \\
\hline YEARS & Included & & & Included & & & Included & & & Included & & \\
\hline F-value & $6.665^{* * *}$ & & & $8.376^{* * *}$ & & & $8.648^{* * *}$ & & & $8.496^{* * *}$ & & \\
\hline $\mathrm{R}^{2}$ & 0.208 & & & 0.255 & & & 0.261 & & & 0.258 & & \\
\hline $\begin{array}{l}\text { Adjusted } \\
\mathrm{R}^{2}\end{array}$ & 0.171 & & & 0.220 & & & 0.227 & & & 0.223 & & \\
\hline
\end{tabular}

Notes: This table represents the OLS regression results. This table show the following variables: Return on Assets (ROA), Return on Equity (ROE), RC existence (RCEX), RC independence (RCNE), RC size (RCSZ), RC meetings (RCME), firm size (BASI), liquidity (LIQR), gearing (GER), audit quality (B4), and Years dummy variables for each year from 2010 to 2014. See Table 2 for the definitions of each variable.

*** Denotes significant at the $1 \%$ level.

** Denotes significant at the 5\% level.

* Denotes significant at the $10 \%$ level

Secondly, our results reveal a negative association between ROA and RC by -5.727 and significant by ( $\mathrm{p}$-value $=0.026$ ) as shown in Table 5. Our results in Table 6 also confirm a negative association between ROA and $\mathrm{RC}$, however such relation is insignificant. These results are in contradiction with the results of Kallamu and Saat (2013) and Hines and Peters (2015) who found a positive association. The fact that they found a positive relationship 
between size of RC and CFP might be due to the different business environments between the UK and US at the time of the studies. Kallamu \& Saat (2013) also report a positive relationship between performance and size of the RC. However, Battaglia and Gallo (2015) reported that market based measures of performance were found to be negatively related to the size of the committee as markets are associated with a stronger RC rather than those with a lower number of members. The negative and weak association, as found by our study, might be explained in terms of the agency problem and coordination problems that emerge as the size of the committee increases. These findings, however, are in accordance with Aebi et al.'s (2012) study, where no significant relationship was revealed between committee size and CFP. This suggests that firms constrained by excessive risk are less profitable and are also more likely to have a bigger risk committee.

Table 6: The Impact of RC on Financial Performance (ROE)

\begin{tabular}{|c|c|c|c|c|c|c|c|c|c|c|c|c|}
\hline & \multicolumn{3}{|c|}{ Model 1} & \multicolumn{3}{|c|}{ Model 2} & \multicolumn{3}{|c|}{ Model 3} & \multicolumn{3}{|c|}{ Model 4} \\
\hline & \multicolumn{3}{|c|}{$\begin{array}{c}\text { Dependent variable: } \\
\text { ROE }\end{array}$} & \multicolumn{3}{|c|}{$\begin{array}{c}\text { Dependent variable: } \\
\text { ROE }\end{array}$} & \multicolumn{3}{|c|}{$\begin{array}{c}\text { Dependent variable: } \\
\text { ROE }\end{array}$} & \multicolumn{3}{|c|}{$\begin{array}{c}\text { Dependent variable: } \\
\text { ROE }\end{array}$} \\
\hline & $\mathbf{t}$ & Sig. & VIF & $\mathbf{t}$ & Sig. & VIF & $\mathbf{t}$ & Sig. & VIF & $\mathbf{t}$ & Sig. & VIF \\
\hline Constant & $3.533^{* * *}$ & .001 & & $3.669^{* * * *}$ & .000 & & $4.714^{* * * *}$ & .000 & & $4.525^{* * *}$ & .000 & \\
\hline RCEX & -0.880 & .381 & 1.014 & - & - & - & - & - & - & - & - & - \\
\hline RCNE & - & - & - & -1.194 & .235 & 1.009 & - & - & - & - & - & - \\
\hline RCME & - & - & - & - & - & - & -2.715 & .008 & 1.023 & - & - & - \\
\hline RCSZ & - & - & - & - & - & - & - & - & - & -2.391 & .019 & 1.016 \\
\hline BASI & $-3.513^{* * *}$ & .001 & 1.140 & $-2.821^{* * *}$ & .006 & 1.262 & $-2.244^{* *}$ & .027 & 1.530 & $-2.494^{* *}$ & .014 & 1.188 \\
\hline LIQ & -0.383 & .702 & 1.059 & -0.239 & .811 & 1.058 & -0.391 & .697 & 1.073 & -0.187 & .852 & 1.052 \\
\hline GEAR & -1.123 & .264 & 1.043 & -1.086 & .280 & 1.055 & -1.024 & .308 & 1.041 & -1.004 & .318 & 1.041 \\
\hline B4 & -0.714 & .477 & 1.282 & -0.265 & .791 & 1.213 & -0.192 & .848 & 1.194 & 0.032 & .975 & 1.212 \\
\hline YEARS & Included & & & Included & & & Included & & & Included & & \\
\hline F- value & 0.525 & & & 0.658 & & & 7.648 & & & 1.530 & & \\
\hline $\mathrm{R}$ square & 0.024 & & & 0.030 & & & 0.080 & & & 0.066 & & \\
\hline $\begin{array}{l}\text { Adjusted } \\
\text { R square }\end{array}$ & -0.021 & & & -0.015 & & & 0.037 & & & 0.023 & & \\
\hline
\end{tabular}

Notes: This table represents the OLS regression results. This table show the following variables: Return on Assets (ROA), Return on Equity (ROE), RC existence (RCEX), RC independence (RCNE), RC size (RCSZ), RC meetings (RCME), firm size (BASI), liquidity (LIQR), gearing (GER), audit quality (B4), and Years dummy variables for each year from 2010 to 2014. See Table 2 for the definitions of each variable.

*** Denotes significant at the $1 \%$ level. 
** Denotes significant at the 5\% level.

* Denotes significant at the $10 \%$ level

Thirdly, our results show a negative and significant association between RC independence and ROA $(\mathrm{t}=-5.676 ; \mathrm{p}$-value $=0.000)$ as shown in Table 5. Our results in Table 6 also confirm a negative association between RC independence and ROA, however such relationship is insignificant. This implies that RC independence is important aspect of the effectiveness of RCs, as pointed out by various previous studies including Aebi et al. (2012). Independent directors of the RC can maximize the value of the firm by providing their expertise as well as monitoring, while improving the performance of the FI by reducing risk taking behaviour during times of crisis. This recommends that firms constrained by excessive risk are less profitable and are also more likely to have a more independent risk committee. Our results are supported by previous studies that found a negative relationship between the percentage of independent directors on RCs and CFP, such as Hoque et al. (2013) and Aebi et al. (2012).

Fourthly, our findings show a negative and significant association between RC meetings and ROA ( $\mathrm{t}=-5.791 ; \mathrm{p}$-value $=0.000)$ as shown in Table 5. Our results in Table 6 also confirm a negative association between $\mathrm{RC}$ independence and $\mathrm{ROA}$, however such relation is insignificant. Hoque et al. (2013) and $\mathrm{Ng}$ et al. (2012) report that the number of meetings might not reflect the quality of discussions. Hence, the relationship between the frequency of meetings and firm performance is not significant in all cases. This contradicts Battaglia and Gallo (2015) who studied Asian bank performance beyond the financial crisis, and the relationship between the average number of meetings of RCs and CFP. It found a positive relationship between the RC meetings and CFP. This can be seen by the fact that while the number of meetings increased for several firms over the years, the financial performance did not. Vafeas (1999) explained that higher frequency of meetings may reflect more control and 
thus, put a negative pressure on the financial performance. More importantly, this implies that firms constrained by excessive risk are less profitable and are also more likely to make more meetings for risk committee.

Table7: Independent Samples Test for ROA in terms of risk committee

\begin{tabular}{c|cc|cccccc}
\hline & Levene's Test & \multicolumn{4}{|c}{ t-test for Equality of Means } \\
\cline { 2 - 7 } & F $\quad$ Sig. & t & df & Sig. $\begin{array}{c}\text { Mean } \\
\text { Difference }\end{array} \begin{array}{c}\text { Std. Error } \\
\text { Difference }\end{array}$ \\
\hline $\begin{array}{c}\text { ROA Equal variances assumed } \\
\text { Equal variances not assumed }\end{array}$ & $3.013^{*} .085$ & $4.790^{* * *}$ & 112 & .000 & 8.29097 & 1.73088 \\
\hline
\end{tabular}

Finally, the results show a negative relationship between the existence of a separate RC and CFP, as well as showing that there is significantly different impact on ROA between companies that have $\mathrm{RC}$ and others that do not $(\mathrm{t}=2.421$, $\mathrm{p}$-value $=0.06)$, which is similar to the findings of this study as shown in Table 7. There is a significantly different impact on ROA between FIs that have RCs and those that do not $(t=4.790$, $\mathrm{p}$-value $=0.085)$, which means that FIs that do not have a RC show better CFP than those that have a RC. This suggests that firms constrained by excessive risk are less profitable and are also more likely to have a bigger risk committee.

It was established in Section 2 through the literature review that the findings on effectiveness of RCs are mixed, with some researchers acknowledging the significance of RCs on improving the CFP, while others negating the notion by claiming that it only adds to the costs or constrain risk taking behaviour. For instance, Ellul and Yerramilli (2010) empirically show that the presence of strong risk management functions lead to lower aggregate risk and downside risk, thus leading to better performance. It emphasizes that firms with better risk controls did better during the crisis, as opposed to those without strong risk control mechanisms. 


\section{Summary and conclusion}

This study focused on examining the association between the existence of separate RCs in the FIs and CFP. More specifically, this study explores how UK listed FIs performed differently based on the existence or non-appearance of a separate RC. Walker (2009) emphasized that all FIs should establish a separate RC to prevent the mistakes that were made in the financial crisis of 2007. Aebi et al. (2012) point out that most of the banks still consider a reduction in operational costs and increase in asset size as the main determinants of profitability. However, the recent crisis has led to the realization that risk management is vital not only for profitability but also for survival of the banks, thus raising the question whether separate RCs should constitute part of the CG structure of banks and other FIs.

Our findings revealed significant negative relationship between various $\mathrm{RC}$ variables (i.e., existence, size, independence, and meetings frequency) and financial performance (i.e., ROA, ROE). It could be argued that effective RC make more pressures and controls over FIs management to strengthen the quality of risk management procedures and policies as well as improving communication regarding risk management among the different stakeholders including management and the board to reduce agency conflicts. This implies that firms constrained by excessive risk are less profitable and are also more likely to have a separate, bigger, and independent risk committee in addition more meetings. This study also has limitations that affected the findings. First, the study only focused on those FIs listed in the UK. Using a larger population frame would have given a larger sample size and provided deeper insight into the research problem. Second, to measure the performance of the firms, only two performance measurement variables (ROA, ROE) was used. Using multiple performance measures to test the relationship would have revealed more profound results. Our study contributes to the current literature in many ways. The fact that significant negative relationship was revealed between $\mathrm{RC}$ and $\mathrm{ROA}$ leads to the recommendation that more 
studies in this evolving area of CG are needed to uncover various different aspects of RCs and their relationship with CFP. It is recommended that more research in the area of RCs are needed to explore various different facets of this important mechanism. It is therefore recommended for future studies to investigate how the size of the FI impacts the risk governance and hence CFP. Furthermore, it is also recommended to replicate this research for smaller FIs to study how RCs influence the financial outcomes. Similarly, this study did not use expertise of the committee members to study the effectiveness of RCs, and future research should also include this variable into the study.

This study offers many implications. First, it provides important insights into FIs that have already established separate RCs, so that they can measure whether their committees are actually fulfilling their functions, or adding costs. Second, the regulators and policy makers should work together to standardize risk management procedures as well as disclosing risk management practices in the annual report to help the shareholders better understand the risk management practices of the firm. The disclosure will also encourage organizations to make sure their RCs are fulfilling their responsibilities and are not being marred by bureaucratic policies. Thus, our findings support current regulatory reforms provided by Walker (2009) and Basel (2015) that focus on an increase in independence and standardization level for the FIs worldwide. 


\section{References}

Abbott, L. J., \& Parker, S. (2000). Auditor selection and audit committee characteristics. Auditing: A Journal of Practice \& Theory, 19(2), 47-66.

Adams, R. B. (2010). Governance of banking institutions. Corporate Governance: A Synthesis of Theory, Research, and Practice. Hoboken, NJ: Wiley \& Sons, 451-468.

Aebi, V., Sabato, G., \& Schmid, M. (2012). Risk management, corporate governance, and bank performance in the financial crisis. Journal of Banking \& Finance, 36(12), 3213-3226.

Al-Hadi, A., Hasan, M. M., \& Habib, A. (2015). Risk committee, firm life cycle, and market risk disclosures. Corporate Governance: An International Review. 24(2), 145-170.

Alnabsha, A., Abdou, H. A., Ntim, C. G., \& Elamer, A. A. (2017). Corporate boards, ownership structures and corporate disclosures: Evidence from a developing country. Journal of Applied Accounting Research, 19(1), 20-41.

Battaglia, F., Gallo, A., \& Graziano, A. E. (2014). Strong boards, risk committee and bank performance: Evidence from India and China. In Corporate Governance in Emerging Markets (pp. 79-105). Springer Berlin Heidelberg.

BCBS. (2015). Corporate governance principles for banks. Basel Committee on Banking Supervision.

Bédard, J., Chtourou, S. M., \& Courteau, L. (2004). The effect of audit committee expertise, independence, and activity on aggressive earnings management. Auditing: A Journal of Practice \& Theory, 23(2), 13-35.

Berger, A. N., Imbierowicz, B., \& Rauch, C. (2016). The roles of corporate governance in bank failures during the recent financial crisis. Journal of Money, Credit and Banking, 48(4), 729-770.

Bhagat, S., \& Black, B. (2002). The non-correlation between board independence and longterm firm performance. The Journal of Corporation Law, 27(2), 231.

Bhagat, S., \& Bolton, B. (2008). Corporate governance and firm performance. Journal of corporate finance, 14(3), 257-273.

Borokhovich, K. A., Brunarski, K. R., Crutchley, C. E., \& Simkins, B. J. (2004). Board composition and corporate use of interest rate derivatives. Journal of Financial Research, 27(2), 199-216.

Choi, I. (2013). When do companies need a board-level risk management committee? Retrieved from: https://scholar.google.co.uk/scholar?q=Choi+\%282013\%29risk +management+includes

Clark, C., De Martinis, M., \& Krambia-Kapardis, M. (2007). Audit quality attributes of European Union supreme audit institutions. European Business Review, 19(1), 40-71.

Core, J. E., Guay, W. R., \& Rusticus, T. O. (2006). Does weak governance cause weak stock returns? An examination of firm operating performance and investors' expectations. The Journal of Finance, 61(2), 655-687. 
Dalton, D. R., Daily, C. M., Johnson, J. L., \& Ellstrand, A. E. (1999). Number of directors and financial performance: A meta-analysis. Academy of Management Journal, 42(6), 674-686.

DeFond, M. L., \& Francis, J. R. (2005). Audit research after sarbanes-oxley. Auditing: A Journal of Practice \& Theory, 24(s-1), 5-30.

Deloitte. (2011). Risk committee resource guide for boards. Retrieved from: http://deloitte.wsj.com /cfo/files/2012/07/risk_committee

Deloitte. (2013). Global risk management survey, eighth edition. Retrieved from: https://www2. deloitte.com/content/dam/Deloitte/global/Documents/FinancialServices/us_aers_grr_grms8_infographic_072313.pdf

Dermine, J. (2013). Bank corporate governance, beyond the global banking crisis. Financial Markets, Institutions \& Instruments, 22(5), 259-281.

Dionne, G., \& Triki, T. (2005). Risk management and corporate governance: The importance of independence and financial knowledge for the board and the audit committee. Available at SSRN 686470.

Elamer, A. A. (2017) Empirical essays on risk disclosures, multi-level governance, credit ratings, and bank value: Evidence from MENA banks. Doctoral thesis, University of Huddersfield

Elamer, A. A., Ntim, C. G., \& Abdou, H. A. (2017). Islamic Governance, National Governance, and Bank Risk Management and Disclosure in MENA Countries. Business \& Society, https://doi.org/10.1177/0007650317746108.

Elamer, A. A., Ntim, C., \& Abdou, H. (2016). Are risk and governance disclosures informative? Evidence from MENA banks' credit ratings. Paper presented at Annual BAM Conference, Newcastle University Business School, Newcastle University, UK.

Ellul, A., \& Yerramilli, V. (2011). Stronger Risk, Lower Controls: Evidence from US Bank Holding Companies. Retrieved from https://scholar.google.co.uk/scholar?q=El $\underline{\text { lul }+ \text { and }+ \text { Y erramilli }+\% 282010 \% 29 \& b \operatorname{bth}=\& h l=e n \& a s}$.

Erkens, D. H., Hung, M., \& Matos, P. (2012). Corporate governance in the 2007-2008 financial crisis: Evidence from financial institutions worldwide. Journal of Corporate Finance, 18(2), 389-411.

Essen, M., Engelen, P. J., \& Carney, M. (2013). Does “Good” corporate governance help in a crisis? The impact of country-and firm-level governance mechanisms in the European financial crisis. Corporate Governance: An International Review, 21(3), 201-224.

Ferrero-Ferrero, I., Fernández-Izquierdo, M. Á., \& Muñoz-Torres, M. J. (2012). The impact of the board of directors characteristics on corporate performance and risk-taking before and during the global financial crisis. Review of Managerial Science, 6(3), 207-226.

Financial Reporting Council (2012). The UK corporate governance code. Retrieved from https://www.google.co.uk/webhp?sourceid=chrome-instant\&ion=1\&espv=2\&ie 
Gupta, K., Krishnamurti, C., \& Tourani-Rad, A. (2013). Is corporate governance relevant during the financial crisis? Journal of International Financial Markets, Institutions and Money, 23, 85-110.

Hines, C. S., \& Peters, G. F. (2015). Voluntary risk management committee formation: Determinants and short-term outcomes. Journal of Accounting and Public Policy, 34(3), 267.

Hoque, M. Z., Islam, M. R., \& Azam, M. N. (2013). Board committee meetings and firm financial performance: An investigation of Australian companies. International Review of Finance, 13(4), 503-528.

Jensen, M. C., \& Meckling, W. H. (1976). Theory of the firm: Managerial behavior, agency costs and ownership structure. Journal of Financial Economics, 3(4), 305-360.

Kallamu, B. S., Saat, N. A. M., \& Senik, R. (2013). Corporate strategy and firm performance in finance industry: the moderating role risk management committee. Management, 2(11), 143-153.

Kirkpatrick, G. (2009). The corporate governance lessons from the financial crisis. $O E C D$ Journal: Financial Market Trends, (1), 61-87.

Marsden, A., \& Prevost, A. K. (2005). Derivatives use, corporate governance, and legislative change: An empirical analysis of New Zealand listed companies. Journal of Business Finance \& Accounting, 32(1-2), 255-295.

Menon, K., \& Williams, J. D. (1994). The use of audit committees for monitoring. Journal of Accounting and Public Policy, 13(2), 121-139.

Minton, B. A., Taillard, J. P., \& Williamson, R. (2014). Financial expertise of the board, risk taking, and performance: Evidence from bank holding companies. Journal of Financial and Quantitative Analysis, 49(02), 351-380.

Minton, B. A., Taillard, J., \& Williamson, R. (2011). Do independence and financial expertise of the board matter for risk taking and performance? Fisher College of Business working paper, (2010-03), 014.

Mongiardino, A., \& Plath, C. (2010). Risk governance at large banks: Have any lessons been learned? Journal of Risk Management in Financial Institutions, 3(2), 116-123.

Moore, M. A., \& Brauneis, M. J. (2008). US subprime crisis: Risk management's next steps. Bank Accounting and Finance, 21(3), 21.

Mubwandarikwa, I. (2013). An exploration of corporate governance and performance of a state-owned-enterprise: a case study of TransNamib in Namibia (Doctoral dissertation, Harold Pupkewitz Graduate School of Business).

Nestor, S. (2009). Bank boards and the financial crisis: a corporate governance study of the 25 largest European banks. Nestor Advisors Limited. Retrieved from: https://scholar.google.co.uk/scholar? q=+Nestor+\%282009\%29+bank+\&btnG=\&hl= en\&as_sdt=. 
Ng, T. H., Chong, L. L., \& Ismail, H. (2012). Is the risk management committee only a procedural compliance? An insight into managing risk taking among insurance companies in Malaysia. The Journal of Risk Finance, 14(1), 71-86.

Peni, E., \& Vähämaa, S. (2012). Did good corporate governance improve bank performance during the financial crisis? Journal of Financial Services Research, 41(1-2), 19-35.

Singh, M., \& Davidson III, W. N. (2003). Agency costs, ownership structure and corporate governance mechanisms. Journal of Banking \& Finance, 27(5), 793-816.

Smith, R. (2003). Audit committees combined code guidance. London: Financial Reporting Council. Retrieved from: http://www.riskavert.com/wp-content/uploads/2011/10/Smi th-Report.

Sori, Z. M., Ramadili, S. M., \& Karbhari, Y. (2009). Audit committee and auditor independence: the bankers' perception. International Journal of Economics and Management, 3(2), 317-331.

Vafeas, N. (1999). Board meeting frequency and firm performance. Journal of Financial Economics, 53(1), 113-142.

Vafeas, N. (2005). Audit committees, boards, and the quality of reported earnings. Contemporary Accounting Research, 22(4), 1093-1122.

Walker, D. (2009). A review of corporate governance in UK banks and other financial industry entities Final recommendations. Retrieved from: http://webarchive.nationalarchive s.gov.uk/.

Weir, C., \& Laing, D. (2001). Governance structures, director independence and corporate performance in the UK. European Business Review, 13(2), 86-95.

Wu, M. C., Lin, H. C., Lin, I. C., \& Lai, C. F. (2009). The Effects of corporate governance on Firm Performance. Working paper. Retrieved from: http://120.107.180.177/1 832/9901/099-2-06p.pdf .

Yatim, P. (2010). Board structures and the establishment of a risk management committee by Malaysian listed firms. Journal of Management \& Governance, 14(1), 17-36.

Yeh, Y., Chung, H., \& Liu, C. (2011). Committee independence and financial institution performance during the 2007-08 credit crunch: Evidence from a Multi-country study. Corporate Governance: An International Review, 19(5), 437-458.

Zaman, M. (2001). Turnbull-generating undue expectations of the corporate governance role of audit committees. Managerial Auditing Journal, 16(1), 5-9.

Zemzem, A., \& Kacemb, O. (2014). Risk management, board characteristics and performance in the Tunisian lending institutions. International Journal of Finance \& Banking Studies, 3(1), 186. 